\title{
The Effects of 5E Learning Cycle Assisted with Spatial Based Population Geography Textbook on Students' Achievement
}

\section{Suwito}

Student of State University of Malang, Indonesia, suwito@unikama.ac.id

\section{Budijanto}

State University of Malang, Indonesia, budijanto19@yahoo.co.id

\section{Budi Handoyo}

State University of Malang, Indonesia, budi.handoyo.fis@um.ac.id

\section{Singgih Susilo}

State University of Malang, Indonesia, singgih.susilo.fis@um.ac.id

Despite its vast usefulness in natural science subjects, the use of the 5E learning cycle in social science is still minimal. The study was quasi-experiment to investigate the effect of the 5E learning cycle model on students' learning achievement in population geography. The participants were two classes of geography education students of academic year 2017/2018 in State University of Malang with forty students each. One class as an experimental group was instructed using the 5E learning cycle, while the other as a control group was traditionally instructed. Pre-test and post-test were administered and analyzed using independent sample t-test to compare learning achievement between two groups. The results showed that the experimental group had significantly improved learning achievement. The results suggest that the learning cycle can be implemented not only on natural sciences courses but also social sciences courses. The use of a learning cycle should be accompanied by a thoroughly planned instructional scenario to maximize the model advantages.

Keywords: students' achievement, textbook, 5E learning cycle, geography, learning

\section{INTRODUCTION}

There were six characteristics of learning geography in the $21^{\text {st }}$ century, namely: (1) student-centered and lecturers proportionally play the role of instructor and facilitator, (2) Oriented to the development of geographical knowledge, attitudes, and skills as well as integrative geographical perspectives, (3) designing a fun, interactive, coordinating and collaborative classroom atmosphere, (4) educators and students both learn in each 
context, (5) develop students' analytical skills through the help of challenging and contextual questions/tasks/problems, (6) Based on scientific learning (Nofrion, 2018). The success of learning as a whole depends on the success of the lecturer in designing learning material. The difficulty of lecturers in collaborating scientific learning with population geography courses influences students' knowledge, skills, and learning outcomes. The $5 \mathrm{E}$ learning cycle is one of learning model that can handle the challenges.

Initially designed for natural science, the 5E learning cycle shows a positive result on the subjects. Previous research on the use of the $5 \mathrm{E}$ learning cycle model in natural science has found that students who learned using this model had improved in academic achievement (Abdi, 2014) mental ability (Bilgin, Coşkun, \& Aktaş, 2013), self-efficacy, learning attitude, and learning satisfaction (Jun, Lee, Park, Chang, \& Kim, 2013), critical thinking (Budprom, Suksringam, \& Singsriwo, 2010; Cahyarini, Rahayu, \& Yahmin, 2016), and knowledge permanence (Tuna \& Kaçar, 2013). However, the application in non-natural science subject is still limited. The only reported research was Kral's who used learning cycles to teach 12th grade English and found significant improvements in the English portion of the American College Test (ACT).

The 5E learning cycle steps are very appropriate for the study of population geography which is always oriented to develop the skills of observing, recording, interpreting, analyzing, classifying, and evaluating both physical and social phenomena. However, the $5 \mathrm{E}$ cycle learning will not be effective without carefully planned learning media such as textbooks. To minimize the weaknesses of the 5E learning cycle, spatial-based learning media is needed. A spatial-based population geography textbook can answer the teacher's challenges in contextual presentation material in the classroom. The distinctive character of the textbook is the content of the material that studies or differentiate a geosphere phenomenon through spatial aspects. Also, the contents of this textbook always pay attention to the principles of distribution/distribution, interrelation, and interaction. This textbook is equipped with colorful images that make students learn contextually. Students can also experiment independently related to the material. Books are also equipped with several sample experiments to conduct, so it is assumed that this textbook is more representative to be studied. The completeness of the material and the existence of several sample images that can be accessed directly by students, and are equipped with student experiment activities that significantly affect classroom learning. The book has indirectly helped teachers to do scientific learning.

It is expected that the application of the 5E learning cycle model assisted with spatialbased population geography textbooks can increase learning motivation and achieve student learning outcomes according to their abilities. Thus, the research tries to explore the effect of the 5E learning cycle model assisted with spatial-based population geography textbooks to students' learning achievement.

\section{LITERATURE REVIEW}

\section{The 5E Learning Cycle}

Learning cycle was introduced by Atkin and Karplus in 1962 as three phases of instructional method consisting of this sequence: preliminary exploration, invention, and 
discovery (Laswon \& Karplus, 2002). Learning cycle facilitates an experience that achieves a secure connection between the pupil's intuitive attitudes and the concepts of the modern scientific point of view. It is parallel with constructivist that learning should let students construct their knowledge and actively participate in the learning process.

There are many versions of the learning cycle, ranging in number from $4 \mathrm{E}$ to $5 \mathrm{E}$ to $7 \mathrm{E}$, yet every learning cycle has at its core the same purpose. This study used the $5 \mathrm{E}$ learning cycle model proposed by Bybee et al. (2006). The 5E stands for engagement, exploration, explanation, elaboration, and evaluation. (1) Engagement: The teacher helps students to engage in a new concept through activities that promote curiosity and elicit prior knowledge. (2) Exploration: Exploration provides students with activities that identify current concepts (particularly misconceptions), processes, and skills as well as facilitate conceptual change. (3) Explanation: The explanation phase provides opportunities for students to demonstrate their conceptual understanding, process skills, or behaviors and for teachers to directly introduce a concept, process, or skill. (4) Elaboration phase facilitates the transfer of ideas to closely related but new situations. (5) Evaluation provides an opportunity for students to use the skills they have acquired and evaluate their understanding.

The 5E learning cycle model has interdependent phases to achieve learning goals and is student-centered. It is in line with the opinion of Sumarni (2010) that the 5E learning cycle model is student-centered, and provides opportunities and flexibility to find out how to learn. The characteristic of the $5 \mathrm{E}$ learning cycle learning model is that the lecturers ask more questions than provide explanations and are oriented towards student activity. It is in line with the opinion of Soeprodjo (2008) that learning using the $5 \mathrm{E}$ learning cycle model is geared towards student activity.

The 5E learning cycle model is more determined by students, and each phase in this model can be passed or applied if students understand the concepts in the previous phase because each new phase and the last phase are interrelated. The model phase 5E learning cycle learning phase is more detailed and more specific, allowing students to be increasingly encouraged to think through discussion and question and answer activities. The greatness of this model is to avoid students from learning methods that tend to memorize and increase learning motivation because they are involved in learning.

The learning cycle model is a teaching procedure consistent with the inquiry nature of science and with the way children naturally learn (Cavallo \& Laubach, 2001). Dass (2015) argues that 5E phases align with essential scientific and engineering practices, thus learning cycle can be used to teach STEM (science, technology, engineering, and mathematics) effectively. Learning using the 5E learning cycle model can provide motivation (motivation) to students to be more active and increase their curiosity. The advantages of the 5E learning cycle model include: (1) being able to motivate students to become more productive and increase their interest; (2) train students to learn to find concepts through experimental activities; (3) train students to deliver verbally learned concepts. In the implementation, learning is no longer just the transfer of knowledge from lecturers to students (teacher center), but the acquisition of concepts oriented to direct student involvement. 


\section{The Spatial-Based Population Geography Textbook}

Spatial-based population geography textbook was a textbook developed by the author in advance on the research and development framework. It specially designed as a tool to develop students' framework analysis that emphasizes the spatial existence. The textbooks is used as (1) primary information providers, because in the book various basic material which can be further developed, (2) instruction materials or learning instruction materials for students; (3) complimentary materials with communicative illustrations and images, (4) practical teaching instructions for lecturers, and (5) material for training for students in conducting self-assessments.

The characteristics of spatial-based population geography textbooks include: (1) the structure is designed to prepare students to study conceptual and analytical material; (2) each chapter is in accordance with the syllabus and is complemented by case studies; (3) it is equipped with geographical skills to improve students' activity; (4) it refers to geographical approaches so that geographic material can be conveyed in its entirety with spatial analysis; (5) it has clear learning instructions so that it can facilitate students to study independently and contextually.

Spatial-based geography textbooks have a unique material analysis framework, namely the concept of matter related to spatial changes is always associated with the temporal dimension. In this case, the material analysis framework has two-time points which are used as a basis for an analysis of the phenomena studied by students.

Spatial-based geography textbooks are also equipped with observational tasks accompanied by their implementation procedures. Steps or methods for doing the preservation task are arranged for students to recognize spatial objects related to spatial structures, patterns, and processes. The spatial objects observed are spatial phenomena that contain essential issues and are related to learning material. This book is also equipped with student worksheets explicitly designed so that students can do elaboration and integration. The steps of elaboration and integration are two actions carried out simultaneously to expand the meaning of the new nature of naturalization that is based on previous student knowledge.

\section{Students' Achievement}

To define, quantify, and measure students' performance is not easy jobs to do. The most common measurement is by achievement test. In the 2013 curriculum of Indonesia, there are three aspects to be assessed to measure students' achievement, namely cognitive, affective, and psychomotor (Ministry of Education and Culture of Indonesia, 2017). Nevertheless, national examination still focuses on the cognitive domain.

This research considered learning achievement only in the cognitive domain, commonly known as academic achievement. Academic achievement represents performance outcome as indications of students' accomplishment in specific focus (Steinmayr et al., 2014). It is a multifaceted construct that comprises different domains of learning. General indicator that indicates academic achievement is grade or performance on an 
educational achievement test. The grades represent intellectual endeavors and mirror the mental capacity of a person.

\section{METHOD}

The study was a quasi-experiment to investigate the effects of learning cycle assisted with spatial-based population geography textbook on students' learning outcome. The experiment used the nonequivalent control group design. The participants were two classes of geography education students of academic year 2017/2018 in State University of Malang with forty students each, one class as experimental group and the other as a control group. Those two groups were chosen since they had nearly equivalent initial competencies, evidenced by no significant differences on mid-semester test results. Lavene's test on pretest also ensured the homogeneity of the two groups.

The research flow was shown in Figure 1. The research started with preliminary research about learning geography at the State University of Malang. Research question and objective was determined afterward. After doing a literature review, the spatial-based population geography textbook, as well as instruments, were developed. The experiment was begun following validations, trials, and revisions.

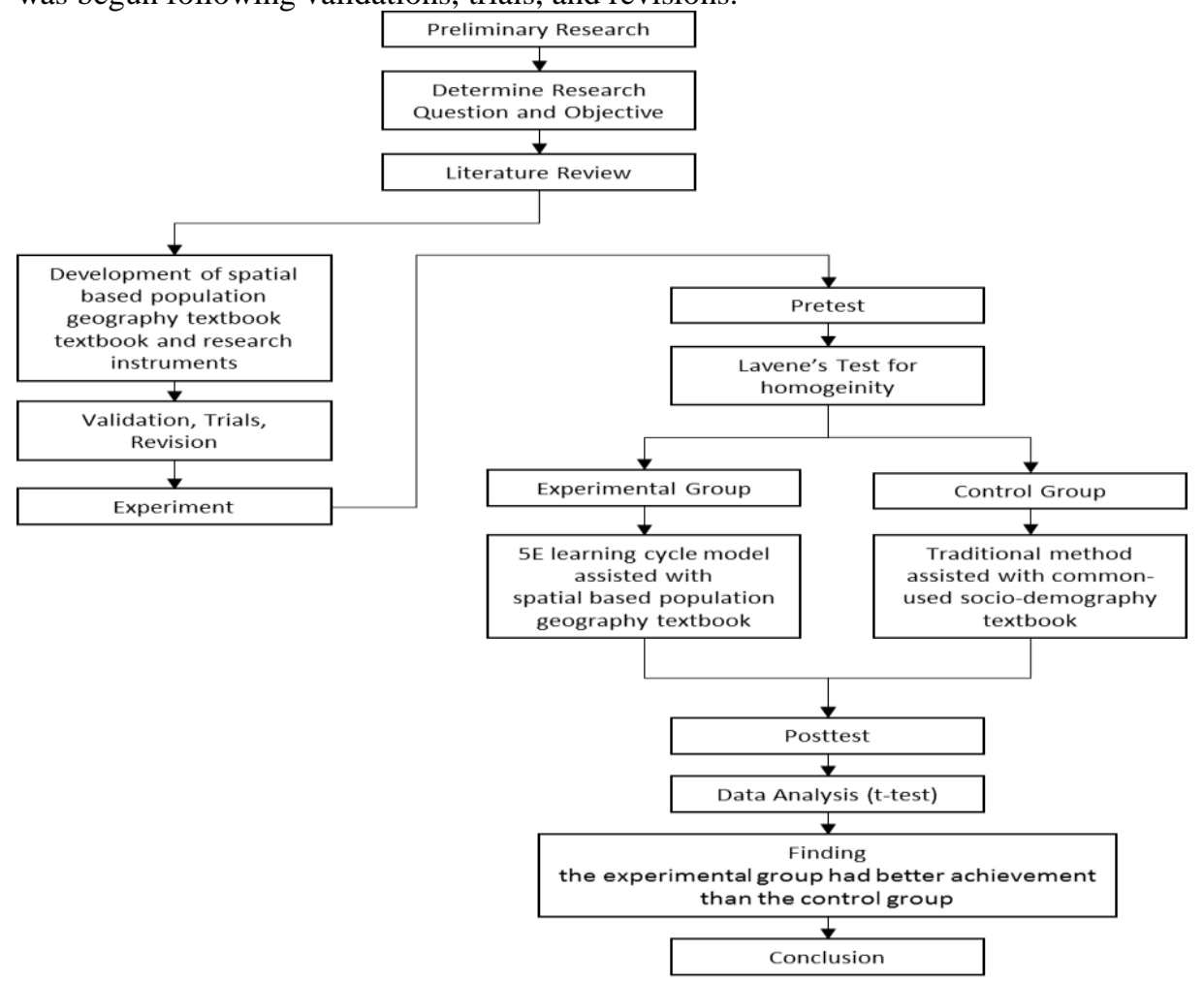

Figure 1

Research Flow 
The instrument used in this study were pretest and posttest. Both tests consisted of 5 items of essay questions. The validity and reliability of devices were previously tested and analyzed. Results from pretest and posttest were analyzed with the method of independent sample t-test with the significance of 5\% to compare the gain score of the experimental and control group.

The study took four weeks, with two hours of class per day per class. The topic included in the lesson was population mobility. The pretest was done in the first hour of the first meeting, while posttest was done in the last session. The same lecturer instructed both groups.

Students in the experimental group were instructed with the 5E learning cycle. Activities and lesson plans were implemented by considering stages of the $5 \mathrm{E}$ learning cycle model. In the engagement phase, lecturer posed some question to arouse students' interest and prior knowledge about population mobility. In the exploration phase, students were encouraged to work in a group to explore the concept of population mobility with the assistance of the spatial-based population geography textbook. The textbook provides some problems to discuss among students. Then, students presented the result of group discussion with some feedback from the other group. In the elaboration phase, a real-world problem about population mobility was given to encourage students to apply the concept. Finally, with the test used in the evaluation phase, students had the opportunity to assess their understanding and abilities.

In the control group, a teacher-oriented strategy representing the traditional approach was used. The teacher used direct teaching and question and answer methods to teach related topics and basic concepts. The teacher provided instruction through lecture and discussion methods to explain the concepts assisted with the commonly used sociodemography textbook.

\section{FINDINGS}

Pretest and posttest result of the experimental and control group are presented in Table 1. Experimental group's pretest mean was 31.43 with a standard deviation of 4.88 , while the control group was 39.11 with a standard deviation of 5.94. Lavene's test on the pretest resulted in no significant difference between the two groups $(p=.19>.05)$. Thus, the experimental and control group could be assumed to be homogenous. After treatments, both experimental and control group had increasing mean value. Experimental group's posttest mean was 71.43 with a standard deviation of 9.41 , and control group was 66.25 with a standard deviation of 8.78 .

Table 1

Pretest and Posttest Result

\begin{tabular}{lllll}
\hline & \multicolumn{2}{l}{ Mean \pm Standard Deviation } & \multirow{2}{*}{$F$} & \multirow{2}{*}{$p$} \\
\cline { 2 - 3 } & Experimental Group & Control Group & & \multirow{2}{*}{1.70} \\
\hline Pretest & $31.43 \pm 4.88$ & $39.11 \pm 5.94$ & \multirow{2}{*}{19} \\
Posttest & $71.43 \pm 9.41$ & $66.25 \pm 8.78$ & & \\
\hline
\end{tabular}


Table 2 shows the gain score-a difference between pretest and posttest result - of the experimental and control group. The experimental group gained $40.00 \pm 10.80$ on average. At the same time, the control group's gain score averaged $27.14 \pm 10.40$. The experimental group showed a significantly higher gain score than the control group, even the value of $\mathrm{p}$ was near zero $(\mathrm{t}=4.53, \mathrm{p}=.00)$. This results showed that the experimental group had better achievement than the control group. Therefore, the use of the $5 \mathrm{E}$ learning cycle does have effects in increasing students' achievement.

Table 2

Gain Score

\begin{tabular}{lllll}
\hline & \multicolumn{2}{l}{ Mean \pm Standard Deviation } & \multirow{2}{*}{$p$} \\
\cline { 2 - 3 } & Experimental Group & Control Group & & \multirow{2}{*}{$p$} \\
\hline Gain Score & $40.00 \pm 10.80$ & $27.14 \pm 10.40$ & 4.53 & .00 \\
\hline
\end{tabular}

\section{DISCUSSION}

Study finds a significant difference between the traditional method and 5E learning cycle assisted with spatial-based population geography textbook. It is consistent with previous findings reported that with learning cycle students got the higher academic achievement (Akar, 2005; Ceylan \& Geban, 2009; Sendag \& Odabasi, 2009; Budprom, Suksringam, \& Singsriwo, 2010; Soeprodjo, Priatmoko, \& Sariana, 2008; Tuna \& Kaçar, 2013). Some factors work on students' achievement in this research, namely the nature of the 5E learning cycle, the use of spatial-based population geography textbook, and the implementation of the $5 \mathrm{E}$ learning cycle assisted with spatial-based population geography textbook.

The nature of the $5 \mathrm{E}$ learning cycle facilitates a better learning process to achieve a better understanding as well as higher achievement. In Engagement phase, the lecturer posed some questions from commonplace about population geography to evoke students' preconception. It is essential since if the previous conceptions are incorrect, then the impact on learning is inevitable. Students usually are not aware of their misconception, so there will be some resistance to change if they were only told that what they believe is incorrect (Kambouri, 2015). Therefore, in the exploration phase, students' can do activities to facilitate their conceptual change or affirmation. By doing explorative learning, students can construct their knowledge using new information or data that they collected. The activities drive them to inquire about their priorities and perceive phenomena from different aspects so that it can help to correct their conceptual errors (Kaptan \& Korkmaz, 2000). After students acquire their concepts, they explain it in the explanation phase. By explaining, students can reflect, refine, discuss, and amend their idea/result. The communication process also helps build meaning and permanence for ideas and makes them public. Listening to others' explanations can also give students opportunities to develop their understandings (NCTM, 2000). Aside from students, the teacher's statement is critical as it may guide students to a deeper understanding (Bybee et al., 2006). Students' knowledge, then, is extended in the elaboration phase. Elaboration can take many different forms. The purest forms of elaboration (paraphrasing and summarizing) allow students to memorize obtained concept, while more complex types of elaboration (problem-solving, application, and analysis) involve 
more significant cognitive effort and more complex thinking, which leads to deeper understanding and more accessible memory structures (Weinstein, Acee, \& Jung, 2011). In the end, students can assess their knowledge in the evaluation phase. A metacognitive approach to instruction can help students learn to take control of their learning by defining learning goals and monitoring their progress in achieving them (NRC, 1999). The teacher also can utilize it to evaluate student progress toward achieving the educational objectives.

The use of the textbook also influences students' achievement. The result of the study shows that the use of spatial-based population geography textbook led to better learning achievement. The issue of whether to use the book in the learning process is dependent upon course content and curricular goals (Klymkowsky, 2007). The characteristic of the course and how the course is taught should be put into consideration in selecting and using a textbook. The possible affecting factor that promotes effectivity of spatial-based population geography textbook in increasing students' achievement is characteristic of the textbook that corresponds to characteristics of the course. Clarke (1978) suggested that population geography is mainly concerned with demonstrating how spatial variation in a population and its various attributes like composition, migration, and growth are related to the spatial variation like places. Thus, the spatial based textbook is the most appropriate media to deliver the course of population geography.

Together, the 5E learning cycle model and spatial based population geography textbook play a synergistic role in improving students' achievement. The textbook facilitates every phase of the $5 \mathrm{E}$ learning cycle with its embedded activity, for an example case study. As one of the features in the book, case study allows students to engage to a contextual problem, explore the problem as well as suggest its solution, explain the rationale, elaborate the problem into another context, and finally evaluate it.

\section{CONCLUSION}

The use of the learning cycle model assisted by spatial-based population geography textbook has a significant influence on student learning outcomes. It is influenced by the characteristics of $5 \mathrm{E}$ learning cycle models and books that always provide opportunities for students to find, apply, and use their learning styles to understand the concept of population geography.

The results suggest that learning cycle can be implemented not only on natural sciences courses but also on social sciences courses. The use of a learning cycle should be accompanied by a thoroughly planned instructional scenario to maximize the model advantages. The assisted textbook should also facilitate students to connect previously learned and to be learned concepts to get a better understanding.

Since the research was limited to only a small group of subjects, further analysis can elaborate it into a bigger scale to validate the result. The $5 \mathrm{E}$ learning cycle also can be tested for other social science subjects to examine another area of the learning outcome, such as students' critical thinking, communication skill, and so on. 


\section{REFERENCES}

Abdi, A. (2014). the effect of inquiry-based learning method on students' academic achievement in science course. Universal Journal of Educational Research, 2(1), 37-41.

Akar, E. (2005). Effectiveness of the 5E learning cycle model on students' understanding of acid-base concepts (Unpublished master's thesis). Middle East Technical University, Ankara, Turkey.

Bilgin, I., Coşkun, H., \& Aktaş, I. (2013). The effect of 5E learning cycle on mental ability of elementary students. Journal of Baltic Science Education, 12(5), 592-607.

Budprom, W., Suksringam, P., \& Singsriwo, A. (2010). Effects of learning environmental education using the 5E-learning cycle with multiple intelligences and teacher's handbook approaches on learning achievements, basic science process skills, and critical thinking of grade 9 students. Pakistan J. of Social Sciences, 7(3), 200-204.

Bybee, R. W., Taylor, J. A., Gardner, A., Van Scotter, P., Powell, J. C., Westbrook, A., \& Landes, N. (2006). The BSCS 5E instructional model: Origins and effectiveness. A report prepared for the Office of Science Education, National Institutes of Health. Colorado Springs, CO: BSCS.

Cahyarini, A., Rahayu, S., \& Yahmin. (2016). The effect of 5E learning cycle instructional model using socio scientific issues (SSI) learning context on students' critical Thinking. Jurnal Pendidikan IPA Indonesia, 2, 222-229.

Cavallo, A., \& Laubach, T. (2001). Students' science perceptions and enrollment decisions in differing learning cycle classroom. Journal of Research in Science Teaching, 38(9), 1029-1062.

Ceylan, E., \& Geban, O. (2009). Facilitating conceptual change in the understanding state of matter and solubility concept using the 5E learning cycle model. Hacettepe University Journal of Education, 36, 41-50.

Clarke, J. (1978). Population geography. Progress in Geography, 2(1), 163-169. doi: 10.1177/030913257800200112.

Dass, P. (2015). Teaching STEM effectively with the learning cycle approach. $K-12$ STEM Education 1(1), 5-12.

Jun, H., Lee, E., Park, H., Chang, A., \& Kim, M. (2013). Use of the 5E learning cycle model combined with problem-based learning for a fundamentals of nursing course. Journal of Nursing Education, 52(12), 681-689.

Kambouri, M. (2015). Investigating early years teachers' understanding and response to children's preconception. European Early Childhood Education Research Journal, 24(6), 907-927. doi: 10.1080/1350293X.2014.970857.

Kaptan, F., \& Korkmaz, H. (2000). Yapisalcilik kurami ve fen ögretimi, Cagdas Egitim Dergisi, 265, 22-27. 
Klymkowsky, M. (2007). Teaching without a textbook: Strategies to focus learning on fundamental concepts and scientific process. CBE-Life Scientific Education, 6(3), 190193. doi: 10.1187/cbe.07-06-0038.

Kolb, D. (2015). Experiential learning: Experience as the source of learning and development. New Jersey: Pearson.

Laswon, A., \& Karplus, R. (2002). The learning cycles. In R. Fuller (Ed.), A love of discovery: Innovations in science education and technology (pp. 51-76). Dordrecht: Springer.

Ministry of Education and Culture of Indonesia. (2017). Peraturan Menteri Pendidikan dan Kebudayaan No 3 tentang Penilaian Hasil Belajar oleh Pemerintah dan Penilaian Hasil Belajar oleh Satuan Pendidikan. [Minister of Education and Culture Regulation No. 3 of 2017 concerning the assessment of learning outcome by government and education unit]. Jakarta: Ministry of Education and Culture of Indonesia.

NCTM. (2000). Principles and standards for school mathematics. Reston: The National Council of Teachers of Mathematics.

Nofrion, N. (2018). Karakterıstık pembelajaran geografi abad 21 [Characteristics of learning geography in 21 st century]. doi: 10.31227/osf.io/kwzjv.

National Research Council. (1999). How people learn: Brain, mind, experience, and school. Washington: The National Academic Press. doi: 10.17226/6160.

Sendag, S., \& Odabasi, H. (2009). Effects of an online problem-based learning course on content knowledge acquisition and critical thinking skills. Computers \& Education, 132-141.

Soeprodjo, Priatmoko, S., \& Sariana, E. (2008). Pengaruh model learning cycle terhadap hasil belajar materi kelarutan dan hasil kali kelarutan. Jurnal Inovasi Pendidikan Kimia, 2(1), 224-229.

Steinmayr R., Meißner A., Weidinger A. F., Wirthwein L. (2014). Academic achievement. Oxford Bibliographies Online. doi:10.1093/obo/9780199756810-0108.

Sumarni, W. (2010). Penerapan learning cycle sebagai upaya meningkatkan keterampilan generik sains inferensia logika mahasiswa melalui perkuliahan praktikum kimia dasar. Jurnal Inovasi Pendidikan Kimia, 4(1), 521-531.

Tuna, A., \& Kaçar, A. (2013). The effect of 5E learning cycle model in teaching trigonometry on students' academic achievement and the permanence of their knowledge. International Journal on New Trends in Education and Their Implications, 4(1), 73-87.

Weinstein, C. E., Acee, T. W., \& Jung, J. (2011). Self-regulation and learning strategies. New Directions for Teaching and Learning, 126, 45-53. doi: 10.1002/tl.443. 